Державна установа "Національний науковий центр “Інститут кардіології імені академіка М. Д. Стражеска" Національної академії медичних наук України”, м. Київ ${ }^{1}$ Національний медичний університет імені О. О. Богомольця, м. Київ²

\title{
ВПЛИВ ЧАСТОТИ СЕРЦЕВИХ СКОРОЧЕНЬ НА ЯКІСТЬ ЖИТТЯ ТА ТЯЖКІСТЬ СИМПТОМІВ АРИТМІї У ПАЦІЄНТІВ ІЗ ПОСТІЙНОЮ ФОРМОЮ ФІБРИЛЯЦІї ПЕРЕДСЕРДЬ НЕКЛАПАННОГО ҐЕНЕЗУ
}

\begin{abstract}
Резюме. Фібриляція передсердь (ФП) - найбільш поширене хронічне порушення ритму серця, що вважається епідемією XXI ст. ФП зазвичай асоціюється із погіршенням ЯЖ. Саме тому їі поліпшення - одне із основних завдань при лікуванні даної групи пацієнтів.

Мета дослідження - оцінити динамічні зміни якості життя (ЯЖ) та тяжкості симптомів аритмії (ТСА) у пацієнтів із постійною формою фібриляції передсердь неклапанного ґенезу на фоні застосування $\beta$-адреноблокаторів (ББ), визначити критичне значення ЧСС, як предиктор негативної динаміки ЯЖ та ТСА при 6-місячному спостереженні, виявити перевагу однієї із стратегій контролю чСС.

Матеріали і методи. 30 пацієнтів послідовно включено у дане дослідження. Тривалість спостереження становила $(238,3 \pm 17,0)$ дня, дизайн передбачав 3 візити. Титрування дози ББ проводилось $(67,7 \pm 10,3)$ дня (інтервал між першим та другим візитами). Прийом максимальної або максимально переносимої дози ББ тривав $(170,6 \pm 17,7)$ дня (інтервал між другим та заключним візитами). Запис ЕКГ, холтерівський моніторинг ЕКГ (ХМ ЕКГ) та анкетування для оцінки ЯЖ та ТСА проводились під час кожного із візитів.

Результати досліджень та їх обговорення. Через 6 місяців у обстежуваної групи пацієнтів значно знизилась середня ЧСС спокою в уд./Хв та мс за результатами ЕКГ порівняно як із першим, так із другим візитами. При цьому під час ХМ подібної закономірності не виявлено. При оцінці показників ЯЖ та ТСА значно зменшилась кількість балів за The Minnesota living with heart failure questionnaire (МАЯЖХСН) станом на останній візит, також зменшилась кількість балів за фрізичним фрактором здоров'я у цій же анкеті, причому станом уже при другому візиті. Проведений кореляційний аналіз виявив зв'язок кількості балів за шкалами TCA EHRA та SAF із показником середньодобової ЧСС за даними 24-х год ХМ ЕКГ. При зіставленні обох стратегій жорсткий контроль показав значну перевагу щодо зниження тривалості мінімального, максимального та середнього інтервалів R-R в уд./хв та підвищення їх тривалості в мс, а отже, і відповідне зниження ЧСС за даними ЕКГ (1, 2, 3 візити), зниження середньої за добу (1, 2, 3 візити), середньої максимальної $(1,2,3$ візити), середньої мінімальної (1, 2, 3 візити), середньої в активний період (1, 2, 3 візити), середньої в пасивний період (1 візит) ЧСС в уд./хв, циркадного індексу (ЦІ) (1, 2 візити) та підвищення середньої за добу (1, 2, 3 візити), середньої максимальної (1, 2, 3 візити), середньої мінімальної (1, 2, 3 візити), середньої в активний період (2, 3 візити), середньої в пасивний період (1 візит) ЧСС в мс за даними ХМ ЕКГ.

Висновки. У пацієнтів із ПФФП неклапанного ґенезу протягом 6-місячного спостереження 24-годинний ХМ показав себе об'єктивним показником контролю ЧСС. Застосування ББ при ПФФП має позитивний вплив на ЯЖ шляхом зниження інтенсивності симптомів СН за шкалою МАЯЖХСН за рахунок поліпшення фрізичного фактора здоров'я. Зафріксована під час ХМ ЕКГ середньодобова ЧСС>91 уд./Хв є предиктором негативної динаміки TCA за шкалами EHRA і SAF. Жорсткий контроль демонструє більш виражений вплив на ЧСС за даними ЕКГ та ХМ ЕКГ. Жодна із стратегій контролю ЧСС не продемонструвала своєї переваги щодо покращення ЯЖ та ТСА.
\end{abstract}

Ключові слова: постійна форма фрібриляції передсердь; контроль частоти серцевих скорочень; якість життя; тяжкість симптомів аритмії.

ВСтУп Фібриляція передсердь (ФП) - найбільш поширене хронічне порушення ритму серця, що вважається епідемією XXI ст [1]. У країнах Європейського Союзу до 2030 р. очікується 14-17 млн пацієнтів із ФП [2]. Розрахунки показують, що рівень поширеності ФП становить приблизно 3 \% у дорослих віком 20 років і старше [3, 4]. Пацієнти із постійною формою (ПФФП) складають майже половину з усіх хворих на ФП, крім того, у половини пацієнтів із ПФФП частота серцевих скорочень (чСС) у спокої становить >80 уд./хв $[5,6]$. Оскільки забезпечення контролю чСС пов'язане із меншим вираженням симптомів аритмії і серцевої недостатності $(\mathrm{CH})$, його адекватність - важлива мішень для поліпшення есрективності лікування при ПФФП. [6] Оптимальна ЧСС у хворих на ПФФП залишається невідомою $[7,8]$. Згідно з існуючими рекомендаціями Європейського товариства кардіологів (ЄТК), із ФП-терапію пацієнтів із ПФФП слід розпочинати із м'якого контролю ЧСС, тобто <110 уд./ хв у спокої незалежно від вираження супутньої $\mathrm{CH}$, якщо симптоми не вимагають більш жорсткого контролю [7]. Робоча група експертів ЄКТ із СН вважає, що чСС 70-100 уд./хв може бути більш прийнятною [8]. Результати лише одного метааналізу вказують на перевагу м'якого контролю ЧСС (до 110 уд./Хв у стані спокою) [9, 10]. Варто відзначити, що в ході клінічного дослідження RACE II, на основі якого і фрормувались рекомендації, ЧСС спокою вимірювалась за допомогою електрокардіограми (ЕКГ), зафріксованої через 2-3 хв знаходження пацієнта в горизонтальному положенні, а 24-годинний холтерівський моніторинг ЕКГ (ХМ ЕКГ) проводився після досягнення цільових рівнів чСС лише при жорсткому контролі [10]. На даний момент відсутній консенсус із приводу тривалості ЕКГ-запису для адекватного відображення контролю ЧСС у пацієнтів із ПФФП [11]. Дані про кореляцію чСС у спокої та при ХМ на даний момент достатньо обмежені [12]. ХМ ЕКг також може використовуватись у якості додаткового методу для більш точного прогнозування якості життя (ЯЖ) у хворих на ПФФП [13]. ФП зазвичай асоціюється із погіршенням Яж [14-17]. Саме тому її поліпшення - одне із основних завдань при лікуванні даної групи пацієнтів [18].

Для оцінки ЯЖ у хворих на ПФФП застосовують опитувальник Medical Outcome Study Short-Form Health Survey (SF-36) $[14,15]$. Він зарекомендував себе як надійний і перевірений інструмент у хворих із ФП [19]. Проте SF-36 слугує для оцінки загальної ЯЖ, але не тяжкості 
симптомів, пов'язаних із ФП, що займає центральне місце в діагностиці та лікуванні хворих із ПФФП і впливає на їх прогноз [20]. Існують більш нові та специфічні опитувальники та шкали для оцінки власне тяжкості симптомів аритмії (ТСA), як-от, The European Heart Rhythm Association symptom classification for atrial fibrillation (шкала EHRA) та Canadian Cardiovascular Society Severity in AF (шкала SAF) [21-24]. Обидві шкали можуть бути цінними як для оцінки впливу симптомів ФП на ЯЖ, так і для допомоги у виборі відповідного лікування [25].

ФП $є$ найпоширенішою аритмією при $\mathrm{CH}$, незалежно від значень фрракції викиду ЛШ (ФВ ЛШ); вона може порушувати фрункцію серця, призводячи до погіршення симптомів С $[6,7]$. Вплив останніх на ЯЖ також має важливе значення, а оцінку їх слід проводити за допомогою The Minnesota living with heart failure questionnaire (MLHFQ, МАЯЖXCH), як однієї із найбільш широко використовуваних у даної когорти хворих $[26,27]$. МАЯЖХСН застосовується у пацієнтів із $\mathrm{CH}$ незалежно від рівня ФВ ЛШ $[28,29]$. Обґрунтоване визначення не тільки загальної оцінки ЯЖ, але і фрізичного та психологічного факторів здоров'я за МАЯЖХСН [29]. Основним критерієм спостереження за пацієнтами із ПФФП повинна бути ретельна оцінка впливу препаратів для контролю чСС на якість життя і толерантність до фрізичних навантажень, а не першочергове зниження частоти скорочення шлуночків [30].

Метою дослідження було оцінити динамічні зміни якості життя (ЯЖ) та тяжкості симптомів аритмії (ТСА) у пацієнтів із постійною формою фрібриляції передсердь неклапанного ґенезу на фроні застосування $\beta$-адреноблокаторів (ББ), визначити критичне значення чСС як предиктор негативної динаміки ЯЖ та ТСА при 6-місячному спостереженні, виявити перевагу однієї із стратегій контролю ЧСС.

МАТЕРІАЛИ І МЕТОДИ У досЛідження пОслідовно включено 30 пацієнтів із ПФФП неклапанного ґенезу. Середній вік хворих складав $(56,9 \pm 1,4)$ року, жінок було 9 (30\%), а чоловіків - 21 (70 \%). Задокументований анамнез ФП становив $(9,5 \pm 1,0)$ року, а власне ПФФП - $(7,5 \pm 0,9)$ року. ПФФП у хворих існувала на фроні міокардіофіброзу в 4 (13,3 \%) та ішемічної хвороби серця - відповідно у 26 (86,7 \%). У 4 (13,3 \%) пацієнтів фріксувалась стабільна стенокардія напруги, постінфрарктний кардіосклероз в анамнезі у 3 (10,0 \%), стентування в анамнезі-в 1 (3,3\%). Гіпертонічна хвороба була у $27(90,0 \%)$ людей, із них I стадія - у 1 (3,3\%), II стадія - в 1 (3,3\%), а III - у 25 (83,3 \%). У 18 (60,0 \%) хворих задокументована гіпертонічна хвороба II ступеня, а у 9 (90,0 \%) - III. За шкалою ризику виникнення серцево-судинних подій SCORE пацієнтів поділили наступним чином: дуже високий ризик засріксовано у 16 (53,3 \%), високий - у 2 (6,7 \%), помірний - у 11 (36,7\%), низький - у 5 (3,3\%). Супутня серцева недостатність I ст. задокументована у 5 (16,7 \%) хворих, у решти 25 (83,3 \%) - II А ст. У 2 (6,7 \%) пацієнтів зафріксовано систолічну дисфрункцію лівого шлуночка за даними ЕхоКГ. Станом на I візит у 8 (26,7 \%) хворих мав місце I фрункціональний клас за шкалою NYHA, у 14 (46,7 \%) - II ФК, у 4 (26,6 \%) - III ФК. Цукровий діабет 2 типу зафріксовано у 7 (23,3 \%) пацієнтів, гостре порушення мозкового кровообігу в анамнезі у 3 (10,0 \%), хронічне обструктивне захворювання легень (ХОЗЛ) у 1 (3,3 \%). Ризик тромбоутворення за шкалою CHA2DS2VASC 1 бал зафріксовано у 10 (30,0\%) хворих, 2 - в 15 (50,0 \%), 3 - у 4 (13,4 \%), 4 - 1 (3,3\%). Ризик кровотечі за шкалою HAS-BLED 1 бал виявлено у 28 (93,3 \%) пацієнтів, а 2 - відповідно у 2 (6,7 \%). Індекс маси тіла в обстежених хворих на момент 1 візиту становив $(33,3 \pm 1,1)$ кг/M², тобто мало місце ожиріння I ступеня. Станом на 2 візит у 9 (30\%) пацієнтів досягнуто жорсткого контролю ЧСС, у 21 (70,0 \%) - м'якого, а на 3 відповідно - у 15 (50 \%) та 15 (50 \%). Для контролю чСС застосовували такі препарати: "Бісопролол" - у 27 (96,7 \%) хворих, "Карведилол" - у 3 (3,3 \%), "Дигоксин" - у 6 (20,0 \%), їх дозування показано у таблиці 1.

Загалом, тривалість даного дослідження складала $(238,3 \pm 17,0)$ дня, а дизайн передбачав 3 візити. Титрування дози ББ - $(67,7 \pm 10,3)$ дня, саме на стільки були розведені у часі перший та другий візити. $(170,6 \pm 17,7)$ дня тривав прийом максимальної або максимально переносимої дози ББ, тобто інтервал між другим та заключним візитами. Досліджувані дані відображено у таблиці 2.

Таблиця 1. Характеристика терапії контролю частоти серцевих скорочень

\begin{tabular}{|l|c|c|c|c|}
\hline \multirow{2}{*}{\multicolumn{1}{|c|}{ Препарат }} & \multicolumn{4}{|c|}{ Середнє значення, $\overline{\boldsymbol{X}} \pm \mathrm{m}(\mathrm{n}=30)$} \\
\cline { 2 - 5 } & 1 & 2 & 3 & $\mathrm{p}$ \\
\hline Бісопролол (мг) & $6,85 \pm 0,45$ & $7,5 \pm 0,46$ & $7,5 \pm 0,46$ & 0,06 \\
\hline Карведилол (мг) & $28,13 \pm 11,8$ & $32,3 \pm 12$ & $32,3 \pm 12$ & 0,37 \\
\hline Дигоксин (мг) & $0,29 \pm$ & $0,24 \pm$ & $0,24 \pm$ & 0,37 \\
\hline
\end{tabular}

Таблиця 2. Дизайн проспективного дослідження

\begin{tabular}{|c|c|c|c|}
\hline Показник & 1 візит & 2 візит & 3 візит \\
\hline \multicolumn{4}{|c|}{ оцінка якості життя і тяжкості симптомів аритмії } \\
\hline Опитувальник SF-36 & + & + & + \\
\hline Міннесотська анкета для хворих із СН & + & + & + \\
\hline Шкала тяжкості симптомів аритмії EHRA & + & + & + \\
\hline Шкала тяжкості симптомів аритмії SAF & + & + & + \\
\hline \multicolumn{4}{|c|}{ інструментальні } \\
\hline ЕКГ з інтервалографрією & + & + & + \\
\hline 24-х год холтерівський моніторинг ЕКГ & + & + & + \\
\hline
\end{tabular}


ЕКГ із посиленням сигналу реєстрували у 3 стандартних відведеннях в електофрізіологічній лабораторії Bard (Johnson \& Johnson, США) для вимірювання інтервалів R-R (в уд./хв і мc) і частоти хвиль f-f (в уд./хв і мс) після 5-ти хв перебування пацієнта в горизонтальному положенні. ХМ ЕКГ проводився із використанням реєстраторів "03250B" ("Сольвейг", Україна) для оцінки середньодобової, максимальної та мінімальної добової, середньої в активний та пасивний період ЧСС (в уд./хв і мс), циркадного індексу, кількості та тривалості пауз (більше 2000 мс). Циркадний індекс (ЦІ) визначався як співвідношення середньої чСС в активний період до середньої чСС у пасивний період (ЦІ=сер. ЧСС а/cер. ЧСС п) [31].

Із метою оцінки загальної ЯЖ пацієнти самостійно заповняли опитувальники SF-36. 36 пунктів опитувальника згруповані у 8 шкал: фрізичне фрункціонування, рольове фрунцціонування, зумовлене фрізичним станом, інтенсивність болю, загальний стан здоров'я, життєва активність, соціальне фрункціонування, рольове фрунціонування зумовлене емоційним станом і психічне здоров'я. Показники кожної шкали варіюють між 0 і 100 балами, де 100 - повне здоров'я. Всі шкали фрормують два показники: фрізичний та психологічний фрактори здоров'я. Результати представляють у вигляді оцінок у балах по 8 шкалами, складених таким чином, що більш висока оцінка вказує на більш високий рівень Яж [32]. Також проводилась оцінка якості життя за опитувальником МАЯЖХСН. Він складається із 21 запитання для оцінки впливу $\mathrm{CH}$ на ЯЖ респондента протягом останнього місяця. Кожне запитання має 5 варіантів відповіді від 0 до 5 залежно від вираження вказаного у ньому симптомі. Сумарний діапазон у балах від 0 (відмінна ЯЖ) до 105 (максимально погана ЯЖ). Крім оцінки за- гальної ЯЖ визначали також фрізичний (8 питань, 0-40 балів), емоційний (5 питань, 0-25 балів) фрактори ЯЖ [29]. Проводилась оцінка ТСА (серцебиття, задишка, запаморочення, пресинкопе або непритомність, біль у грудях, слабкість або втома), для чого пацієнти самостійно визначали ступінь впливу симптомів ПФФП на повсякденну активність згідно зі шкалою EHRA (4 класи: від 1 (відсутність симптомів) до 4 (симптоми інвалідизації, які унеможливлюють звичайну щоденну активність)) i SAF (5 класів: від 0 (відсутність симптомів) до 4 (симптоми мають сильний вплив на загальну якість життя пацієнта)) [18, 23].

Статистичний аналіз отриманих даних здійснювали за допомогою програмного пакета MedCalc v.15.8.0 (MedCalc Software bvba, 1993-2015, Belgium). Аналіз відповідності розподілу кількісних ознак до закону нормального розподілу проводили за допомогою W-тесту Шапіро-Уілка. Використано ANOVA для повторних вимірювань (у випадку нормального закону розподілу), критерій Фрідмана (у випадку закону розподілу, відмінного від нормального). Порівняння абсолютної і відносної (\%) частот виявлення якісних (номінальних і рангових) показників проводили за таблицями спряження (кростабуляції) з оцінюванням критерію $\chi^{2}$-Пірсона. Для визначення незалежних предикторів комбінованої кінцевої точки проводився уніваріантний та покроковий мультиваріантний логістичний регресійний аналіз. Ступінь зв'язку фракторних ознак із ризиком виникнення комбінованої кінцевої точки оцінювали за допомогою відношення шансів (ВШ), для якого визначали 95 \% довірчий інтервал (ДІ). Рівнем статистичної значущості вважали $р<0,05$.

РЕЗУЛЬТАТИ ДОСЛІДЖЕНЬ ТА ЇХ ОБГОВОРЕННЯ У таблиці 3 відображено дані ЕКГ з інтервалографрією у

Таблиця 3. Характеристика динамічних показників ЕКГ та холтерівського моніторингу ЕКГ

\begin{tabular}{|c|c|c|c|c|}
\hline \multirow{2}{*}{ Показник } & \multicolumn{4}{|c|}{ Середнє значення, $\overline{\boldsymbol{X}} \pm \mathrm{m}(\mathrm{n}=30)$} \\
\hline & 1 & 2 & 3 & $p$ \\
\hline $\mathrm{R}-\mathrm{R} \min (\mathrm{MC})$ & $952,00 \pm 42,00$ & $934,00 \pm 33,00$ & $999,00 \pm 32,00$ & 0,30 \\
\hline R-R min (уд./хв) & $66,70 \pm 2,90$ & $67,40 \pm 3,30$ & $61,90 \pm 2,10$ & 0,30 \\
\hline $\mathrm{R}-\mathrm{R} \max (\mathrm{MC})$ & $495,00 \pm 24,00$ & $501,00 \pm 18,00$ & $522,00 \pm 19,00$ & 0,17 \\
\hline R-R max (уд./хв) & $128,20 \pm 5,20$ & $124,00 \pm 4,20$ & $119,10 \pm 4,10$ & 0,17 \\
\hline R-R cep (MC) & $682,00 \pm 26,00$ & $687,00 \pm 21,00$ & $725,00 \pm 19,00^{\star \#}$ & 0,004 \\
\hline R-R сер (уд./хв) & $91,80 \pm 3,50$ & $90,30 \pm 3,40$ & $84,40 \pm 2,30^{\star \#}$ & 0,004 \\
\hline частота f-f сер (мc) & $140,50 \pm 2,80$ & $138,10 \pm 2,80$ & $137,90 \pm 2,80$ & 0,20 \\
\hline частота f-f сер (уд./хв) & $432,10 \pm 8,70$ & $440,10 \pm 9,80$ & $440,80 \pm 9,70$ & 0,20 \\
\hline cep. ЧСС (Mc) & $658,00 \pm 18,00$ & $655,00 \pm 19,00$ & $657,00 \pm 16,00$ & $>0,9$ \\
\hline сер. ЧСС (уд./хв) & $93,20 \pm 2,60$ & $93,80 \pm 2,80$ & $93,00 \pm 2,40$ & $>0,9$ \\
\hline cep. 4CC max (MC) & $568,00 \pm 17,00$ & $573,00 \pm 17,00$ & $576,00 \pm 14,00$ & 0,56 \\
\hline cep. ЧСС max (уд./Хв) & $108,50 \pm 3,30$ & $107,30 \pm 3,10$ & $106,10 \pm 2,70$ & 0,56 \\
\hline cep. 4CC min (MC) & $730,00 \pm 21,00$ & $722,00 \pm 20,00$ & $735,00 \pm 18,00$ & 0,79 \\
\hline сер. ЧСС min (Уд./хв) & $84,20 \pm 2,50$ & $85,20 \pm 2,60$ & $83,30 \pm 2,40$ & 0,79 \\
\hline cep. ЧЧС a (Mc) & $625,00 \pm 17,00$ & $619,00 \pm 18,00$ & $619,00 \pm 16,00$ & 0,74 \\
\hline сер. ЧЧС а (уд./Хв) & $98,30 \pm 2,80$ & $99,50 \pm 3,00$ & $98,90 \pm 2,70$ & 0,74 \\
\hline cep. ЧСС п (мс) & $753,00 \pm 25,00$ & $738,00 \pm 22,00$ & $760,00 \pm 20,00$ & 0,54 \\
\hline сер. ЧСС п (уд./хв) & $82,30 \pm 2,70$ & $83,30 \pm 2,50$ & $80,60 \pm 2,20$ & 0,54 \\
\hline ЦІ & $1,19 \pm 0,03$ & $1,17 \pm 0,03$ & $1,20 \pm 0,03$ & 0,23 \\
\hline паузи (к-сть) & $13,70 \pm 3,90$ & $9,80 \pm 3,90$ & $10,30 \pm 3,90$ & 0,24 \\
\hline паузи max (мс) & $1507,00 \pm 216,00$ & $1330,00 \pm 219,00$ & $1142,00 \pm 215,00$ & 0,24 \\
\hline
\end{tabular}

Примітки: 1) * - відмінність від першого вимірювання статистично значуща, р<0,05;

2) \# в відмінність від другого вимірювання статистично значуща, p<0,05. 
стані спокою та ХМ ЕКГ, зафріксовані під час кожного із візитів. Виявлено статистично значиму різницю таких показників: середня ЧСС спокою в уд./Хв та мс за результатами ЕКГ. Тобто у хворих на ПФФП через 6 місяців на фоні постійного прийому відтитрованої дози ББ ЧСС, засріксованої на ЕКГ, знизилась із $(91,8 \pm 3,5)$ уд./хв до $(84,4 \pm 2,3)$ уд./хв $(p=0,004)$ і відповідно із $(682 \pm 26)$ мс до $(725 \pm 19)$ мс $(p=0,004)$. При цьому під час ХМ подібної закономірності не виявлено: $(93,2 \pm 2,6)$ уд./хв і $(93,0 \pm 2,4)$ уд./хв та відповідно (658 18$)$ мс і $(657 \pm 16)$ мс.

Отримані дані узгоджуються із результатами інших досліджень. За даними літератури, тільки довгострокові (6-ти год і більше) записи ЕКГ забезпечують високу кореляцію із 24-х год за середнім значенням чСС [13]. Також встановлено, що у 21,3 \% пацієнтів із ПФФП цільова ЧСС у спокої не корелює із такою при 24-х год ХМ ЕКГ [14]. Варто мати на увазі, що у дослідженні RACE II XM ЕКГ проводився лише хворим, які підлягали стратегії жорсткого контролю ЧСС, а при фрормуванні рекомендованих показників ЧСС оцінювались дані записів ЕКГ [10].

При оцінці показників ЯЖ та ТСА (табл. 4) виявлено наступні результати: статистично значимо зменшилась кількість балів за МАЯЖХСН станом на останній візит, також знизилась кількість балів з фрізичного фактора здоров'я у цій же анкеті, причому станом на другий проміжний візит. Отже, у пацієнтів із ПФФП на фоні постійного прийому цільової дози ББ через 6 місяців спостерігається покращення ЯЖ за рахунок зменшення інтенсивності симптомів $\mathrm{CH}$ згідно з загальною шкалою МАЯЖХCH - із $(35,5 \pm 3,6)$ бала до $(31,4 \pm 3,2)$ бала $(p=0,008)$, а за фрізичним фрактором здоров'я позитивна динаміка спостерігається уже через 2 місяці, тобто після підбору і титрування дози ББ - із $(14,4 \pm 1,4)$ бала до $(12,8 \pm 1,2)$ бала $(p=0,03)$.

Згідно з даними літератури, у всіх пацієнтів із $\mathrm{CH}$ відзначається помітне зниження ЯЖ як за загальними, так і за діагнозспецифічними опитувальниками (МАЯЖХCH). При чому ЯЖ пацієнтів із систолічною дисфрункцією лШ та без неї істотно не відрізняється [28]. Відомо, що пацієнти із $\mathrm{CH}$ та збереженою фракцією викиду ЛШ (ЗФВ ЛШ) мають схожі, хоча і не такі тяжкі патофрізіологічні характеристики, подібні клінічні симптоми, ЯЖ, оцінену самостійно згідно опитувальником МАЯЖХСН, терміни повторної госпіталізації, а також 6-місячну смертність порівняно 3 хворими на $\mathrm{CH}$ та систолічну диссуункцію ЛШ [28, 33, 34]. Оцінка за МАЯЖХCH $є$ надійною, достовірною і чутливою мірою несприятливого впливу на ЯЖ пацієнтів із $\mathrm{CH}$ із ЗФВ ФВ ЛШ [35]. Показник МАЯЖХСН у балах $є$ незалежним предиктором як серцево-судинних подій, так і смерті серед пацієнтів із СН [36]. Загальний стан здоров'я і фрізичне функціонування, оцінене за допомогою опитувальника МАЯЖХСН, забезпечує додаткову прогностичну інформацію про виживання у даної групи пацієнтів [37]. Орієнтація на поліпшення переносимості симптомів і Яж є важливою метою лікування всіх хворих із СН [38]. Інтенсивне лікування, у тому числі ББ, поліпшує якість життя пацієнтів (за МАЯЖХСН), а також знижує ймовірність госпіталізації пацієнтів із $\mathrm{CH}$ [39]. Доведено ефективність використання бісопрололу в максимально рекомендованих дозах для амбулаторного лікування хворих на $\mathrm{CH}$, при цьому значно покращується ЯЖ (опитувальник МАЯЖХСН) [40]. Також визначено позитивний вплив карведилолу на функцію серця у хворих на СН та якість життя цих пацієнтів, що виражається зменшенням кількості балів за опитувальником МАЯЖХСН [41].

При аналізі хворих на ПФФП, згідно з МАЯЖХСН, дані літератури присвячені впливу на ЯЖ або абляції атріовентрикулярного вузла із наступною імплантацією штучного водія ритму, або імплантації кардіоресинхронізуючого пристрою, або абляції гирла легеневих вен. Ми знайшли лише одне джерело, в якому висвітлено оцінку ЯЖ за МАЯЖХСН у хворих на ПФФП при медикаментозній терапії. При цьому за умови досягнення жорсткого контролю чСС ЯЖ за опитувальником МАЯЖХСН при лікуванні ББ протягом 3 місяців спостереження не покращувалась [42]. Варто відзначити, що оцінка ЯЖ проводилась у пацієнтів із СН та СД лШ. У групі, яку ми обстежували, таких було лише 2. На момент проведення дослідження даних літе-

Таблиця 4. Характеристика динамічних показників якості та життя тяжкості симптомів аритмії

\begin{tabular}{|c|c|c|c|c|}
\hline \multirow{2}{*}{ Показник } & \multicolumn{4}{|c|}{ Середнє значення, $\overline{\boldsymbol{X}} \pm \mathrm{m}(\mathrm{n}=30)$} \\
\hline & 1 & 2 & 3 & $p$ \\
\hline SAF клас (бали) & $1,93 \pm 0,16$ & $1,93 \pm 0,16$ & $1,90 \pm 0,160$ & $>0,9$ \\
\hline EHRA клас (бали) & $1,53 \pm 0,10$ & $1,53 \pm 0,10$ & $1,53 \pm 0,11$ & $>0,9$ \\
\hline Міннесота (бали) & $35,50 \pm 3,60$ & $32,20 \pm 3,20$ & $31,40 \pm 3,20^{*}$ & 0,008 \\
\hline Міннесота, фріз. фр-р (бали) & $14,40 \pm 1,40$ & $12,80 \pm 1,20^{*}$ & $12,70 \pm 1,20$ & 0,03 \\
\hline Міннесота, ем. фр-р (бали) & $5,30 \pm 0,90$ & $4,60 \pm 0,80$ & $4,80 \pm 0,90$ & 0,89 \\
\hline PF (фріз. фр-ння, бали) & $60,00 \pm 3,90$ & $57,50 \pm 4,60$ & $55,50 \pm 4,60$ & 0,08 \\
\hline $\mathrm{RP}$ (рол. фріз. фр-ння, бали) & $30,80 \pm 6,50$ & $31,70 \pm 7,50$ & $30,80 \pm 7,50$ & 0,89 \\
\hline ВР (інтен. болю, бали) & $58,40 \pm 4,30$ & $64,10 \pm 4,00$ & $61,10 \pm 4,50$ & 0,22 \\
\hline GH (заг. стан здор., бали) & $44,30 \pm 2,20$ & $44,80 \pm 2,70$ & $46,80 \pm 2,60$ & 0,89 \\
\hline VT (жит. акт., бали) & $50,70 \pm 3,20$ & $52,00 \pm 2,90$ & $52,50 \pm 2,70$ & 0,54 \\
\hline SF (соц. фр-ння, бали) & $67,50 \pm 3,50$ & $70,00 \pm 3,20$ & $70,80 \pm 4,00$ & 0,90 \\
\hline $\mathrm{RE}$ (рол. ем. фр-ння, бали) & $37,80 \pm 7,50$ & $38,90 \pm 7,70$ & $33,30 \pm 7,70$ & 0,85 \\
\hline MH (пс. здор., бали) & $60,90 \pm 2,40$ & $60,40 \pm 2,60$ & $62,90 \pm 2,30$ & 0,41 \\
\hline PH (фіз. к-нт. здор., бали) & $39,50 \pm 1,60$ & $40,00 \pm 1,60$ & $39,50 \pm 1,80$ & $>0,9$ \\
\hline МН (псих. к-нт. здор., бали) & $40,10 \pm 1,60$ & $40,60 \pm 1,50$ & $40,70 \pm 1,60$ & $>0,9$ \\
\hline
\end{tabular}

Примітка. * - відмінність від першого вимірювання статистично значуща, p<0,05. 
ратури щодо оцінки ЯЖ у хворих на ПФФП та супутню $\mathrm{CH}$ із збереженою фракцією викиду не виявлено. Це фракт дає нам підставу вважати застосування МАЯЖХСН для оцінки ЯЖ у даної групи пацієнтів не тільки в якості наукової новизни, але і виправданим, зважаючи на поріг статистичної значущості отриманих даних.

На наступному етапі проводилось виявлення критичного значення чСС як предиктора негативної динаміки ЯЖ та ТСА у пацієнтів із ПФФП неклапанного ґенезу протягом піврічного проспективного спостереження. При проведенні кореляційного аналізу було виявлено зв'язок кількості балів за шкалами TCA EHRA та SAF із показником середньодобової ЧСС (уд./Хв) за даними 24 год XМ ЕКГ. Для вибору порогу ЧСС, при якому спостерігається погіршення ТСА за означеними вище шкалами, було використано метод побудови та аналізу кривих операційних характеристик (ROC-curve).

При проведенні аналізу тяжкості симптомів аритмії за шкалою EHRA за погіршення стану вважали кількість балів більше 1. На рисунку 1 наведена ROC-крива цього тесту. При проведенні аналізу встановлено наявність зв'язку кількості балів за шкалою TCA EHRA із показником середньодобової ЧСС (Уд./Хв) за даними 24-х год ХМ ЕКГ, площа під кривою $\mathrm{AUC}=0,71$ (95 \% BI 0,60-0,80), статистично значуще більше 0,5 ( $p<0,001)$.

У таблиці 5 наведено прогностичні характеристики тесту при різних порогових значеннях показника середньодобової ЧСС (уд./Хв) за даними 24-х год ХМ ЕКГ.

При виборі значення порогу показника середньодобової чСС (уд./Хв), при якому показник чутливості та специфічності тесту будуть близькі між собою, отримуємо середньодобову ЧСС (уд./хв)crit=91уд./хв. Тобто при середньодобовій ЧСС>91 уд./Хв за даними ХМ ЕКГ прогнозується погіршення TCA (EHRA>1 бала), при серед-

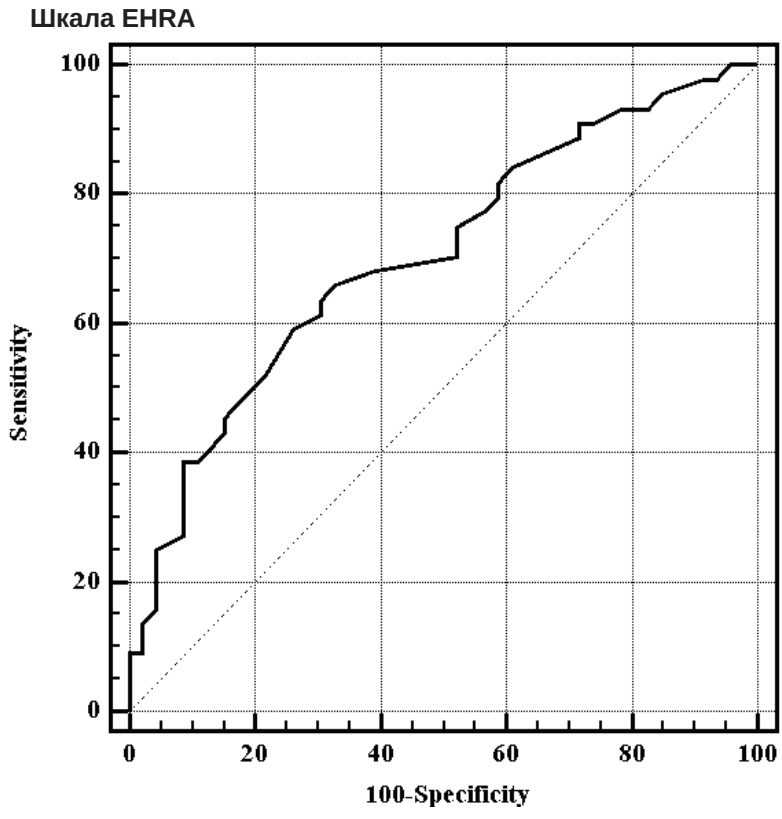

Pис. 1. ROC-крива прогнозування TCA за шкалою EHRA за показником середньодобової ЧСС (Уд./Хв), AUC= 0,71 (95 \% ВІ 0,60-0,80).

ньодобовій чСС $\leq 91$ уд./хв прогнозується кількість балів за шкалою EHRA=1. Для обраного порогу чутливість тесту становить 65,9 \% (95 \% ВІ 50,1 \%-79,5 \%), специсрічність - 67,4 \% (95\% BI 52,0\%-80,5\%).

Для проведення аналізу TCA за шкалою SAF за погіршення стану вважали кількість балів більше 1. На рисунку 2 наведена ROC-крива для цього випадку. При проведенні аналізу встановлено наявність зв'язку кількості балів за шкалою TCA SAF із показником середньо-

Таблиця 5. Прогностичні характеристики тесту оцінки EHRA при різних порогових значеннях показника середньодобової частоти серцевих скорочень

\begin{tabular}{|c|c|c|c|c|}
\hline Показник & Чутливість & $95 \% \mathrm{BI}$ & Специфічність & 17,39 \\
\hline$>77$ & 93,18 & $81,03-98,60$ & 21,74 & $7,80-31,40$ \\
\hline$>80$ & 93,18 & $81,30-98,60$ & 26,09 & $10,90-36,40$ \\
\hline$>81$ & 90,91 & $78,30-97,50$ & 28,26 & $14,30-41,10$ \\
\hline$>82$ & 90,91 & $78,30-97,50$ & 28,26 & $16,00-43,50$ \\
\hline$>83$ & 88,64 & $75,40-96,20$ & 39,13 & $25,10-54,50$ \\
\hline$>84$ & 84,09 & $69,90-93,40$ & 41,30 & $27,00-56,80$ \\
\hline$>85$ & 81,82 & $67,30-91,80$ & 41,30 & $27,00-56,80$ \\
\hline$>86$ & 79,55 & $64,70-90,20$ & 43,48 & $28,90-58,90$ \\
\hline$>87$ & 77,27 & $62,20-88,50$ & 47,83 & $32,90-63,10$ \\
\hline$>88$ & 75,00 & $59,70-86,80$ & 47,83 & $32,90-63,10$ \\
\hline$>89$ & 70,45 & $54,80-83,20$ & 60,87 & $45,40-74,90$ \\
\hline$>90$ & 68,18 & $52,40-81,40$ & 67,39 & $52,00-80,50$ \\
\hline$>91$ & 65,91 & $50,10-79,50$ & 69,57 & $54,20-82,30$ \\
\hline$>92$ & 63,64 & $47,80-77,60$ & 69,57 & $54,20-82,30$ \\
\hline$>93$ & 61,36 & $45,50-75,60$ & 73,91 & $58,90-85,70$ \\
\hline$>94$ & 59,09 & $43,20-73,70$ & 78,26 & $63,60-89,10$ \\
\hline$>95$ & 52,27 & $36,70-67,50$ & 82,61 & $68,60-92,20$ \\
\hline$>96$ & 47,73 & $32,50-63,30$ & 84,78 & $71,10-93,70$ \\
\hline$>97$ & 45,45 & $30,40-61,20$ & 84,78 & $71,10-93,70$ \\
\hline$>98$ & 43,18 & 86,96 & $73,70-95,10$ \\
\hline$>99$ & 40,91 & $28,30-59,00$ & 89,13 & $76,40-96,40$ \\
\hline$>100$ & 38,64 & $26,30-56,80$ & 91,30 & $79,20-97,60$ \\
\hline$>101$ & 38,64 & $24,40-54,50$ & & \\
\hline
\end{tabular}


добової чСС (уд./хв) за даними 24-х год ХМ ЕКГ, площа під кривою $\mathrm{AUC}=0,62$ (95 \% ВІ 0,51-0,72), статистично значуще більше 0,5 ( $p=0,049)$.

У таблиці 6 наведено прогностичні характеристики тесту при різних порогових значеннях показника середньодобової ЧСС (уд./Хв) за даними 24-х год ХМ ЕКГ.

При виборі значення порогу показника середньодобової чСС (уд./хв), при якому показник чутливості та специфрічності тесту будуть близькі між собою, отримуємо середньодобову ЧСС (уд./Хв)crit=91уд./хв. Тобто при середньодобовій ЧСС>91 уд./Хв, за даними ХМ ЕКГ, прогнозується погіршення симптомів TCA (SAF>1 бала), при середньодобовій чСС $\leq 91$ уд./хв прогнозується кількість балів за шкалою SAF=1. Для обраного порогу чутливість тесту становить 57,4 \% (95 \% ВІ 43,2 \%-70,8 \%), специфрічність - 63,9 \% (95 \% ВІ 46,2 \%-79,2 \%).

На наступному етапі дослідження проводилось порівняння показників, отриманих при застосуванні кожної із стратегій контролю ЧСС. На момент 2 візиту в 9 пацієнтів вдалось досягнути жорсткого, а у 21 - м'якого контролю чСС, а через півроку при 3 візиті відповідно у 15 та 15 хворих.

При жорсткому контролі чСС через 6 місяців не виявлено статистично значимих змін як досліджуваних показників ЕКГ і ХМ ЕКГ, так і ЯЖ та ТСА (табл. 7 і 8).

У пацієнтів, які підлягали стратегії м'якого контрою чСС протягом періоду спостережень значимих змін досліджуваних показників як ЕКГ і ХМ ЕКГ, так і ЯЖ і ТСА також не виявлено (табл. 9 і 10).

Наступним етапом дослідження зіставлення отриманих показників ЕКГ, ХМ ЕКГ, ЯЖ та ТСА при обох стратегіях контрою ЧСС за візитами.

При порівнянні обох стратегій жорсткий контроль показав значиму перевагу щодо зниження тривалості міні-

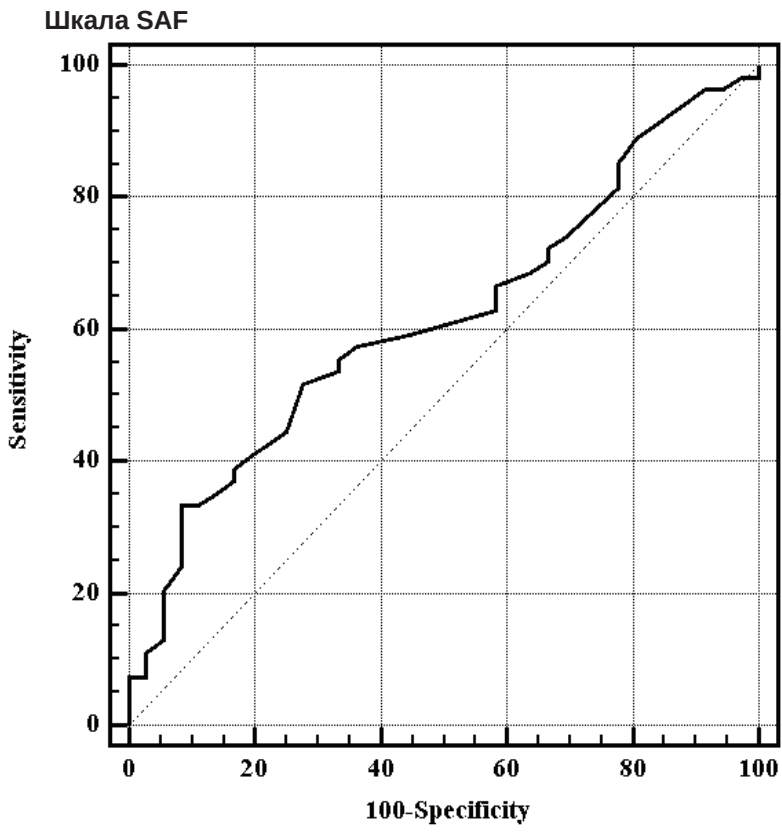

Pиc. 2. ROC-крива прогнозування тяжкості симптомів аритмії за шкалою SAF за середньодобової чСС (уд./хв), AUC=0,62 (95 \% BI 0,51-0,72).

мального (R-R min), максимального (R-R max) та середнього інтервалів R-R (R-R cep.) в уд./хв та підвищення їх тривалості в мс, а отже, і відповідне зниження чСС за даними ЕКГ (1, 2, 3 візити), зниження середньої за добу (сер. чСС) (1, 2, 3 візити), середньої максимальної (сер. чСС max) (1, 2, 3 візити), середньої мінімальної (сер. ЧСС min) (1, 2, 3 візити), середньої в активний період (сер. ччС а) (1, 2, 3 візити), середньої в пасивний період

Таблиця 6. Прогностичні характеристики тесту оцінки SAF при різних порогових значеннях показника середньодобової частоти серцевих скорочень

\begin{tabular}{|c|c|c|c|c|}
\hline Показник & Чутливість & $95 \% \mathrm{BI}$ & Специфрічність & $95 \% \mathrm{BI}$ \\
\hline$>77$ & 90,74 & $79,70-96,90$ & 16,67 & $6,40-32,80$ \\
\hline$>80$ & 88,89 & $77,40-95,80$ & 19,44 & $8,20-36,00$ \\
\hline$>81$ & 85,19 & $72,90-93,40$ & 22,22 & $10,10-39,20$ \\
\hline$>83$ & 81,48 & $68,60-90,70$ & 22,22 & $10,10-39,20$ \\
\hline$>84$ & 74,07 & $60,30-85,00$ & 30,56 & $16,30-48,10$ \\
\hline$>85$ & 72,22 & $58,40-83,50$ & 33,33 & $18,60-51,00$ \\
\hline$>86$ & 70,37 & $56,40-82,00$ & 33,33 & $18,60-51,00$ \\
\hline$>87$ & 68,52 & $54,40-80,50$ & 36,11 & $20,80-53,80$ \\
\hline$>88$ & 66,67 & $52,50-78,90$ & 41,67 & $25,50-59,20$ \\
\hline$>89$ & 62,96 & $48,70-75,70$ & 41,67 & $25,50-59,20$ \\
\hline$>90$ & 59,26 & $45,00-72,40$ & 55,56 & $38,10-72,10$ \\
\hline$>91$ & 57,41 & $43,20-70,80$ & 63,89 & $46,20-79,20$ \\
\hline$>92$ & 55,56 & $41,40-69,10$ & 66,67 & $49,00-81,40$ \\
\hline$>93$ & 53,70 & $39,60-67,40$ & 66,67 & $49,00-81,40$ \\
\hline$>94$ & 51,85 & $37,80-65,70$ & 72,22 & $54,80-85,80$ \\
\hline$>95$ & 44,44 & $30,90-58,60$ & 75,00 & $57,80-87,90$ \\
\hline$>96$ & 40,74 & $27,60-55,00$ & 80,56 & $64,00-91,80$ \\
\hline$>97$ & 38,89 & $25,90-53,10$ & 83,33 & $67,20-93,60$ \\
\hline$>98$ & 37,04 & $24,30-51,30$ & 83,33 & $67,20-93,60$ \\
\hline$>99$ & 35,19 & $22,70-49,40$ & 86,11 & $70,50-95,30$ \\
\hline$>100$ & 33,33 & $21,10-47,50$ & 88,89 & $73,90-96,90$ \\
\hline$>101$ & 33,33 & $21,10-47,50$ & 91,67 & $77,50-98,20$ \\
\hline$>104$ & 24,07 & $13,50-37,60$ & 91,67 & $77,50-98,20$ \\
\hline
\end{tabular}


Таблиця 7. Характеристика показників ЕКГ та холтерівського моніторингу ЕКГ при жорсткому контролі частоти серцевих скорочень

\begin{tabular}{|c|c|c|c|c|}
\hline \multirow{2}{*}{ Показник } & \multicolumn{4}{|c|}{ Середнє значення, $\overline{\boldsymbol{X}} \pm \mathrm{m}$} \\
\hline & 1 & 2 & 3 & $\mathrm{p}$ \\
\hline $\mathrm{R}-\mathrm{R} \min (\mathrm{MC})$ & $1185,11 \pm 58,04$ & $1074,00 \pm 29,35$ & $1122,40 \pm 33,91$ & 0,16 \\
\hline R-R min (уд./хв) & $51,55 \pm 2,38$ & $56,20 \pm 1,52$ & $54,14 \pm 1,63$ & 0,19 \\
\hline $\mathrm{R}-\mathrm{R} \max (\mathrm{MC})$ & $632,44 \pm 48,82$ & $609,56 \pm 32,61$ & $582,40 \pm 24,43$ & 0,67 \\
\hline R-R max (уд./хв) & $99,64 \pm 7,80$ & $100,84 \pm 5,65$ & $105,77 \pm 4,78$ & 0,81 \\
\hline R-R cep. (Mc) & $852,33 \pm 26,26$ & $810,34 \pm 16,07$ & $809,07 \pm 14,23$ & 0,10 \\
\hline R-R сер. (уд./хв) & $70,90 \pm 2,07$ & $74,27 \pm 1,41$ & $74,46 \pm 1,24$ & 0,10 \\
\hline частота f-f cep. (мс) & $139,56 \pm 6,55$ & $139,56 \pm 6,81$ & $139,20 \pm 4,86$ & 0,38 \\
\hline частота f-f сер. (уд./хв) & $437,29 \pm 19,68$ & $440,10 \pm 29,34$ & $439,61 \pm 17,77$ & 0,59 \\
\hline сер. ЧСС (мс) & $714,23 \pm 28,36$ & $743,70 \pm 31,58$ & $691,80 \pm 18,53$ & 0,25 \\
\hline сер. ЧСС (уд./хв) & $85,08 \pm 3,39$ & $81,83 \pm 3,42$ & $87,55 \pm 2,20$ & 0,34 \\
\hline cep. ЧCC $\max (\mathrm{Mc})$ & $617,89 \pm 24,45$ & $650,04 \pm 29,16$ & $604,17 \pm 18,30$ & 0,31 \\
\hline cep. ЧСС max (уд./Хв) & $98,33 \pm 3,90$ & $93,77 \pm 4,12$ & $100,51 \pm 2,84$ & 0,38 \\
\hline cep. 4CC $\min (\mathrm{MC})$ & $802,33 \pm 33,47$ & $817,08 \pm 34,44$ & $772,41 \pm 19,12$ & 0,42 \\
\hline cep. ЧСС $\min ($ (уд./Хв) & $75,83 \pm 3,18$ & $74,42 \pm 2,95$ & $78,32 \pm 1,86$ & 0,54 \\
\hline cep. ЧЧС a (мс) & $674,58 \pm 25,53$ & $708,54 \pm 27,60$ & $656,35 \pm 17,70$ & 0,22 \\
\hline сер. ЧЧС а (уд./хв) & $89,92 \pm 3,24$ & $85,72 \pm 3,36$ & $92,29 \pm 2,34$ & 0,29 \\
\hline cep. ЧСС п (мс) & $833,70 \pm 47,41$ & $810,08 \pm 46,53$ & $786,43 \pm 21,32$ & 0,64 \\
\hline сер. ЧСС п (уд./Хв) & $73,84 \pm 4,15$ & $75,84 \pm 3,89$ & $77,07 \pm 2,07$ & 0,65 \\
\hline ЦІ & $1,09 \pm 0,06$ & $1,10 \pm 0,06$ & $1,15 \pm 0,03$ & 0,94 \\
\hline паузи (к-сть) & $24,00 \pm 8,91$ & $23,78 \pm 11,78$ & $16,80 \pm 6,94$ & 0,92 \\
\hline паузи max (мс) & $1895,33 \pm 369,80$ & $1875,89 \pm 365,18$ & $1535,47 \pm 297,24$ & 0,29 \\
\hline
\end{tabular}

Таблиця 8. Характеристика показників якості життя та тяжкості симптомів аритмії при жорсткому контролі частоти серцевих скорочень

\begin{tabular}{|l|c|c|c|c|}
\hline \multirow{2}{*}{\multicolumn{1}{c|}{ Показник }} & \multicolumn{3}{c|}{ Середнє значення, $\overline{\boldsymbol{X}} \pm \mathrm{m}$} \\
\cline { 2 - 5 } & 1 & 2 & \multicolumn{2}{c|}{$\mathrm{p}$} \\
\hline SAF клас (бали) & $1,67 \pm 0,29$ & $1,67 \pm 0,29$ & $1,67 \pm 0,19$ & 0,11 \\
\hline EHRA клас (бали) & $1,22 \pm 0,15$ & $1,22 \pm 0,15$ & $1,27 \pm 0,12$ & 0,14 \\
\hline Міннесота (бали) & $34,11 \pm 8,37$ & $33,78 \pm 6,81$ & $29,73 \pm 4,24$ & 0,97 \\
\hline Міннесота, фріз. фр-р (бали) & $13,33 \pm 3,24$ & $12,44 \pm 2,64$ & $11,93 \pm 1,82$ & 0,64 \\
\hline Mіннесота, ем. фр-р (бали) & $4,67 \pm 1,76$ & $4,89 \pm 1,57$ & $4,33 \pm 1,11$ & 0,97 \\
\hline PF (фіз. фр-ння, бали) & $66,11 \pm 7,30$ & $60,56 \pm 10,05$ & $60,67 \pm 6,88$ & 0,09 \\
\hline RP (рол. фріз. фр-ння, бали) & $47,22 \pm 12,80$ & $44,44 \pm 16,02$ & $44,00 \pm 11,39$ & 0,79 \\
\hline BP (інтен. болю, бали) & $61,78 \pm 9,62$ & $67,89 \pm 8,93$ & $60,93 \pm 6,49$ & 0,27 \\
\hline GH (заг. стан здор., бали) & $43,78 \pm 4,65$ & $46,56 \pm 5,34$ & $47,73 \pm 3,58$ & 0,70 \\
\hline VT (жит. акт., бали) & $57,22 \pm 5,66$ & $52,78 \pm 4,18$ & $54,33 \pm 2,92$ & 0,44 \\
\hline SF (соц. фр-ння, бали) & $68,06 \pm 7,54$ & $69,44 \pm 5,93$ & $72,50 \pm 6,00$ & 0,77 \\
\hline RE (рол. ем. фр-ння, бали) & $55,56 \pm 15,71$ & $55,54 \pm 12,43$ & $51,11 \pm 10,72$ & 0,47 \\
\hline MH (пс. здор., бали) & $63,11 \pm 3,87$ & $59,56 \pm 5,56$ & $63,20 \pm 2,51$ & 0,79 \\
\hline PH (фіз. к-нт. здор., бали) & $41,84 \pm 3,44$ & $41,83 \pm 3,56$ & $40,84 \pm 2,73$ & 0,08 \\
\hline MH (псих. к-нт. здор., бали) & $42,91 \pm 3,40$ & $42,07 \pm 2,18$ & $42,98 \pm 2,01$ & 0,50 \\
\hline
\end{tabular}

Таблиця 9. Характеристика показників ЕКГ та холтерівського моніторингу ЕКГ при м'якому контролі частоти серцевих скорочень

\begin{tabular}{|c|c|c|c|c|}
\hline \multirow{2}{*}{ Показник } & \multicolumn{4}{|c|}{ Середнє значення, $\overline{\boldsymbol{X}} \pm \mathrm{m}$} \\
\hline & 1 & 2 & 3 & $\mathrm{p}$ \\
\hline $\mathrm{R}-\mathrm{R} \min (\mathrm{MC})$ & $852,57 \pm 38,42$ & $874,29 \pm 38,78$ & $875,20 \pm 30,81$ & 0,32 \\
\hline R-R min (уд./хв) & $73,07 \pm 3,02$ & $72,25 \pm 4,35$ & $69,77 \pm 2,49$ & 0,32 \\
\hline $\mathrm{R}-\mathrm{R} \max (\mathrm{MC})$ & $436,57 \pm 14,66$ & $454,86 \pm 12,69$ & $462,40 \pm 18,43$ & 0,32 \\
\hline $\mathrm{R}-\mathrm{R}$ max (уд./хв) & $140,44 \pm 4,57$ & $134,02 \pm 3,81$ & $132,33 \pm 4,69$ & 0,37 \\
\hline R-R cep. (Mc) & $607,95 \pm 19,72$ & $634,38 \pm 20,96$ & $640,67 \pm 10,08$ & 0,42 \\
\hline R-R сер. (уд./хв) & $100,80 \pm 3,27$ & $97,16 \pm 4,00$ & $94,48 \pm 2,37$ & 0,42 \\
\hline
\end{tabular}


Продовження табл. 9

\begin{tabular}{|c|c|c|c|c|}
\hline \multirow{2}{*}{ Показник } & \multicolumn{4}{|c|}{ Середнє значення, $\overline{\boldsymbol{X}} \pm \mathrm{m}$} \\
\hline & 1 & 2 & 3 & $p$ \\
\hline частота f-f cep. (мc) & $140,95 \pm 3,05$ & $137,52 \pm 2,85$ & $136,53 \pm 2,76$ & 0,33 \\
\hline частота f-f cер. (уд./хв) & $429,73 \pm 9,42$ & $440,00 \pm 9,01$ & $441,92 \pm 8,78$ & 0,33 \\
\hline cep. ЧСС (мс) & $633,79 \pm 20,68$ & $617,02 \pm 17,64$ & $619,06 \pm 19,86$ & 0,63 \\
\hline сер. ЧСС (уд./Хв) & $96,67 \pm 3,13$ & $99,00 \pm 3,13$ & $98,60 \pm 3,80$ & 0,63 \\
\hline cep. ЧCC $\max (\mathrm{MC})$ & $546,29 \pm 19,81$ & $540,17 \pm 15,72$ & $545,09 \pm 17,18$ & 0,78 \\
\hline сер. ЧСС max (уд./хв) & $112,73 \pm 4,07$ & $112,98 \pm 3,33$ & $111,78 \pm 3,93$ & 0,80 \\
\hline cep. ЧCC min (Mc) & $698,89 \pm 23,06$ & $681,42 \pm 19,61$ & $693,53 \pm 25,31$ & 0,62 \\
\hline сер. ЧСС min (уд./Хв) & $87,78 \pm 2,98$ & $89,73 \pm 2,98$ & $88,47 \pm 3,91$ & 0,82 \\
\hline cep. ЧЧС a (Mc) & $603,22 \pm 20,58$ & $580,25 \pm 17,10$ & $578,62 \pm 18,85$ & 0,31 \\
\hline сер. ЧЧС а (уд./хв) & $101,83 \pm 3,49$ & $105,38 \pm 3,40$ & $105,58 \pm 4,21$ & 0,63 \\
\hline cep. ЧСС п (мс) & $717,96 \pm 26,32$ & $707,23 \pm 21,24$ & $729,03 \pm 29,22$ & 0,56 \\
\hline сер. ЧСС п (уд./хв) & $85,84 \pm 3,17$ & $86,55 \pm 2,92$ & $84,26 \pm 3,55$ & 0,63 \\
\hline ЦІ & $1,23 \pm 0,04$ & $1,20 \pm 0,04$ & $1,24 \pm 0,05$ & 0,98 \\
\hline паузи (к-сть) & $9,29 \pm 3,86$ & $3,86 \pm 1,45$ & $9,47 \pm 6,10$ & 0,77 \\
\hline паузи max (мс) & $1340,05 \pm 262,62$ & $1095,33 \pm 258,87$ & $932,33 \pm 308,38$ & 0,92 \\
\hline
\end{tabular}

Таблиця 10. Характеристика показників якості життя та тяжкості симптомів аритмії при м'якому контролі частоти серцевих скорочень

\begin{tabular}{|c|c|c|c|c|}
\hline \multirow{2}{*}{ Показник } & \multicolumn{4}{|c|}{ Середнє значення, $\overline{\boldsymbol{X}} \pm \mathrm{m}$} \\
\hline & 1 & 2 & 3 & $p$ \\
\hline SAF клас (бали) & $2,05 \pm 0,20$ & $2,05 \pm 0,19$ & $2,13 \pm 0,26$ & 0,89 \\
\hline EHRA клас (бали) & $1,67 \pm 0,13$ & $1,67 \pm 0,13$ & $1,73 \pm 0,18$ & 0,88 \\
\hline Міннесота (бали) & $36,05 \pm 3,76$ & $31,43 \pm 3,65$ & $33,78 \pm 6,81$ & 0,59 \\
\hline Міннесота, фріз. фр-р (бали) & $15,10 \pm 1,45$ & $13,00 \pm 1,38$ & $13,47 \pm 1,65$ & 0,93 \\
\hline Міннесота, ем. фр-р (бали) & $5,57 \pm 1,00$ & $4,48 \pm 1,00$ & $5,20 \pm 1,37$ & 0,88 \\
\hline PF (фіз. фр-ння, бали) & $57,38 \pm 4,55$ & $56,19 \pm 5,05$ & $50,33 \pm 5,97$ & 0,19 \\
\hline RP (рол. фріз. фр-ння, бали) & $23,81 \pm 7,21$ & $26,19 \pm 8,18$ & $21,67 \pm 9,40$ & 0,74 \\
\hline ВР (інтен. болю, бали) & $56,95 \pm 4,72$ & $62,52 \pm 4,31$ & $61,33 \pm 6,54$ & 0,67 \\
\hline GH (заг. стан здор., бали) & $44,57 \pm 2,59$ & $44,00 \pm 3,08$ & $45,80 \pm 3,85$ & 0,75 \\
\hline VT (жит. акт., бали) & $47,86 \pm 3,74$ & $51,67 \pm 3,77$ & $50,67 \pm 4,68$ & 0,30 \\
\hline SF (соц. ср-ння, бали) & $67,26 \pm 3,90$ & $70,24 \pm 3,90$ & $69,17 \pm 5,30$ & 0,77 \\
\hline $\mathrm{RE}$ (рол. ем. фр-ння, бали) & $30,15 \pm 7,94$ & $31,74 \pm 9,34$ & $15,55 \pm 9,12$ & 0,20 \\
\hline МН (пс. здор., бали) & $60,00 \pm 3,05$ & $60,76 \pm 2,85$ & $62,67 \pm 3,92$ & 0,94 \\
\hline PH (фріз. к-нт. здор., бали) & $38,33 \pm 1,73$ & $39,09 \pm 1,70$ & $38,09 \pm 2,24$ & 0,70 \\
\hline МН (псих. к-нт. здор., бали) & $38,77 \pm 1,82$ & $39,80 \pm 1,92$ & $38,44 \pm 2,27$ & 0,72 \\
\hline
\end{tabular}

(1 візит) (сер. чСС п) ЧСС в уд./хв, циркадного індексу (ЦІ) (1, 2 візити) та підвищення середньої за добу (сер. чСС) (1, 2, 3 візити), середньої максимальної (сер. чСС max) (1, 2, 3 візити), середньої мінімальної (сер. чСС min) (1, 2, 3 візити), середньої в активний період (сер. ччС а)
(2, 3 візити), середньої в пасивний період (сер. чСС п) (1 візит) чСС у мс за даними ХМ ЕКГ (табл. 11-13).

При зіставленні впливу обох стратегій на ЯЖ та ТСА статистично значимих переваг не виявлено у жодної (табл. 14-16).

Таблиця 11. Порівняльна характеристика показників ЕКГ та холтерівського моніторингу ЕКГ при жорсткому та м'якому контролі частота серцевих скорочень (1 візит)

\begin{tabular}{|c|c|c|c|}
\hline \multirow{2}{*}{ Показник } & \multicolumn{3}{|c|}{ Середнє значення, $\overline{\boldsymbol{X}} \pm \mathrm{m}$} \\
\hline & 1, ж. к. & 1, м. к. & $p$ \\
\hline $\mathrm{R}-\mathrm{R} \min (\mathrm{MC})$ & $1185,11 \pm 58,04$ & $852,57 \pm 38,42$ & 0,008 \\
\hline $\mathrm{R}-\mathrm{R}$ min (уд./Хв) & $51,55 \pm 2,38$ & $73,07 \pm 3,02$ & $<0,001$ \\
\hline $\mathrm{R}-\mathrm{R} \max (\mathrm{MC})$ & $632,44 \pm 48,82$ & $436,57 \pm 14,66$ & $<0,001$ \\
\hline $\mathrm{R}-\mathrm{R} \max$ (уд./хв) & $99,64 \pm 7,80$ & $140,44 \pm 4,57$ & $<0,001$ \\
\hline R-R cep. (мс) & $852,33 \pm 26,26$ & $607,95 \pm 19,72$ & 0,008 \\
\hline R-R сер. (уд./хв) & $70,90 \pm 2,07$ & $100,80 \pm 3,27$ & 0,008 \\
\hline частота f-f cep. (мc) & $139,56 \pm 6,55$ & $140,95 \pm 3,05$ & 0,83 \\
\hline частота f-f cep. (уд./хв) & $437,29 \pm 19,68$ & $429,73 \pm 9,42$ & 0,83 \\
\hline
\end{tabular}


Продовження табл. 11

\begin{tabular}{|c|c|c|c|}
\hline \multirow{2}{*}{ Показник } & \multicolumn{3}{|c|}{ Середнє значення, $\overline{\boldsymbol{X}} \pm \mathrm{m}$} \\
\hline & 1, ж. к. & 1, м. к. & $p$ \\
\hline cep. ЧСС (Mc) & $743,70 \pm 28,36$ & $633,79 \pm 20,68$ & 0,04 \\
\hline сер. ЧСС (уд./хв) & $85,08 \pm 3,39$ & $96,67 \pm 3,11$ & 0,04 \\
\hline cep. ЧСС max (MC) & $617,89 \pm 24,45$ & $546,29 \pm 19,81$ & 0,046 \\
\hline cep. ЧСС max (уд./хв) & $98,33 \pm 3,90$ & $112,73 \pm 4,07$ & 0,04 \\
\hline cep. ЧСС $\min (\mathrm{Mc})$ & $802,33 \pm 33,47$ & $698,89 \pm 23,06$ & 0,02 \\
\hline сер. ЧСС min (уд./хв) & $75,83 \pm 3,18$ & $87,78 \pm 2,98$ & 0,02 \\
\hline cep. ЧЧС a (мс) & $674,58 \pm 25,53$ & $603,22 \pm 20,58$ & 0,06 \\
\hline сер. ЧЧС а (уд.Іххв) & $89,92 \pm 3,24$ & $101,83 \pm 3,49$ & 0,048 \\
\hline cep. ЧСС п (мс) & $833,70 \pm 47,41$ & $717,96 \pm 26,32$ & 0,03 \\
\hline сер. ЧСС п (уд./хв) & $73,84 \pm 4,15$ & $85,84 \pm 3,17$ & 0,04 \\
\hline ЦІ & $1,09 \pm 0,06$ & $1,23 \pm 0,04$ & 0,04 \\
\hline паузи (к-сть) & $24,00 \pm 8,91$ & $9,29 \pm 3,86$ & 0,09 \\
\hline паузи max (мс) & $1895,89 \pm 369,80$ & $1340,05 \pm 262,62$ & 0,16 \\
\hline
\end{tabular}

Примітка. * - відмінність статистично значима, p<0,05.

Таблиця 12. Порівняльна характеристика показників ЕКГ та холтерівського моніторингу та ЕКГ при жорсткому та м'якому контролі частоти серцевих скорочень (2 візит)

\begin{tabular}{|c|c|c|c|}
\hline \multirow{2}{*}{ Показник } & \multicolumn{3}{|c|}{ Середнє значення, $\overline{\boldsymbol{X}} \pm \mathrm{m}$} \\
\hline & 2, ж. к. & 2, м. К. & $p$ \\
\hline $\mathrm{R}-\mathrm{R} \min (\mathrm{MC})$ & $1074,00 \pm 29,35$ & $874,29 \pm 38,78$ & 0,004 \\
\hline R-R min (уд./хв) & $56,20 \pm 1,52$ & $72,25 \pm 4,35$ & 0,02 \\
\hline $\mathrm{R}-\mathrm{R} \max (\mathrm{MC})$ & $609,56 \pm 32,61$ & $454,86 \pm 12,69$ & $<0,001$ \\
\hline R-R max (уд./хв) & $100,84 \pm 5,65$ & $134,02 \pm 3,81$ & $<0,001$ \\
\hline R-R cep. (Mc) & $810,34 \pm 16,07$ & $634,38 \pm 20,96$ & 0,008 \\
\hline R-R сер. (уд./хв) & $74,27 \pm 1,41$ & $97,16 \pm 4,00$ & 0,04 \\
\hline частота f-f cep. (мc) & $139,56 \pm 6,81$ & $137,52 \pm 2,85$ & 0,53 \\
\hline частота f-f сер. (уд./хв) & $440,10 \pm 29,34$ & $440,00 \pm 9,01$ & 0,58 \\
\hline сер ЧСС (мс) & $743,70 \pm 31,58$ & $617,02 \pm 17,64$ & $<0,001$ \\
\hline сер. ЧСС (уд./хв) & $81,83 \pm 3,42$ & $99,00 \pm 3,13$ & 0,03 \\
\hline cep. ЧCC max (Mc) & $650,04 \pm 29,16$ & $540,17 \pm 15,72$ & 0,001 \\
\hline cep. ЧСС max (уд./Хв) & $93,77 \pm 4,12$ & $112,98 \pm 3,33$ & 0,002 \\
\hline cep. 4CC min (MC) & $817,08 \pm 34,44$ & $681,42 \pm 19,61$ & 0,001 \\
\hline сер. ЧСС min (уд./хв) & $74,42 \pm 2,95$ & $89,73 \pm 2,98$ & 0,02 \\
\hline cep. ЧЧС a (мc) & $708,54 \pm 27,60$ & $578,62 \pm 18,85$ & $<0,001$ \\
\hline сер. ЧЧС а (уд./хв) & $85,72 \pm 3,36$ & $105,38 \pm 3,40$ & 0,002 \\
\hline cep. ЧСС п (мс) & $810,08 \pm 46,53$ & $707,23 \pm 21,24$ & 0,26 \\
\hline сер. ЧСС п (уд./хв) & $75,84 \pm 3,89$ & $86,55 \pm 2,92$ & 0,31 \\
\hline ЦІ & $1,10 \pm 0,06$ & $1,20 \pm 0,04$ & 0,04 \\
\hline паузи (к-сть) & $23,78 \pm 11,78$ & $3,86 \pm 1,45$ & 0,58 \\
\hline паузи max (мс) & $1875,89 \pm 365,18$ & $1095,33 \pm 258,87$ & 0,48 \\
\hline
\end{tabular}

Примітка. * - відмінність статистично значима, p<0,05.

Таблиця 13. Порівняльна характеристика показників ЕКГ та холтерівського моніторингу ЕКГ при жорсткому та м'якому контролі частоти серцевих скорочень (3 візит)

\begin{tabular}{|c|c|c|c|}
\hline \multirow{2}{*}{ Показник } & \multicolumn{3}{|c|}{ Середнє значення, $\overline{\boldsymbol{X}} \pm \mathrm{m}$} \\
\hline & 3, ж. к. & 3, м. к. & $p$ \\
\hline $\mathrm{R}-\mathrm{R} \min (\mathrm{MC})$ & $1122,40 \pm 33,91$ & $875,20 \pm 30,81$ & $<0,001$ \\
\hline $\mathrm{R}-\mathrm{R} \min ($ (уд./хв) & $54,14 \pm 1,63$ & $69,77 \pm 2,49$ & $<0,001$ \\
\hline $\mathrm{R}-\mathrm{R} \max (\mathrm{Mc})$ & $582,40 \pm 24,43$ & $462,40 \pm 18,43$ & $<0,001$ \\
\hline R-R max (уд./хв) & $105,77 \pm 4,78$ & $132,33 \pm 4,69$ & $<0,001$ \\
\hline R-R cep. (Mc) & $809,07 \pm 14,23$ & $640,67 \pm 10,08$ & $<0,001$ \\
\hline R-R cep. (уд./хв) & $74,46 \pm 1,24$ & $94,48 \pm 2,37$ & $<0,001$ \\
\hline
\end{tabular}


Продовження табл. 13

\begin{tabular}{|c|c|c|c|}
\hline \multirow{2}{*}{ Показник } & \multicolumn{3}{|c|}{ Середнє значення, $\overline{\boldsymbol{X}} \pm \mathrm{m}$} \\
\hline & 3, ж. к. & 3, м. к. & $\mathrm{p}$ \\
\hline частота f-f cep. (Mc) & $139,20 \pm 4,86$ & $136,53 \pm 2,76$ & 0,64 \\
\hline частота f-f cep. (уд./хв) & $439,61 \pm 17,77$ & $441,92 \pm 8,78$ & 0,65 \\
\hline cep. ЧСС (мc) & $691,80 \pm 18,53$ & $619,06 \pm 19,86$ & 0,01 \\
\hline сер. ЧСС (уд./хв) & $87,55 \pm 2,20$ & $98,60 \pm 3,80$ & 0,015 \\
\hline cep. ЧCC max (Mc) & $604,17 \pm 18,30$ & $545,09 \pm 17,18$ & 0,03 \\
\hline cep. ЧСС max (уд./хв) & $100,51 \pm 2,84$ & $111,78 \pm 3,93$ & 0,03 \\
\hline cep. ЧCC $\min (\mathrm{Mc})$ & $772,41 \pm 19,12$ & $693,53 \pm 25,31$ & 0,02 \\
\hline cep. ЧСС min (уд./хв) & $78,32 \pm 1,86$ & $88,47 \pm 3,91$ & 0,02 \\
\hline cep. ЧЧС a (мc) & $656,35 \pm 17,70$ & $578,62 \pm 18,85$ & 0,006 \\
\hline сер. ЧЧС а (уд./хв) & $92,29 \pm 2,34$ & $105,58 \pm 4,21$ & 0,008 \\
\hline сер. ЧСС п (Mc) & $786,43,08 \pm 21,32$ & $729,03 \pm 29,22$ & 0,12 \\
\hline сер. ЧСС п (уд./хв) & $77,07 \pm 2,07$ & $84,26 \pm 3,55$ & 0,09 \\
\hline ЦІ & $1,15 \pm 0,03$ & $1,24 \pm 0,05$ & 0,28 \\
\hline паузи (к-сть) & $16,80 \pm 6,94$ & $9,47 \pm 6,10$ & 0,18 \\
\hline паузи max (мс) & $1535,47 \pm 297,24$ & $932,33 \pm 308,38$ & 0,13 \\
\hline
\end{tabular}

Примітка. * - відмінність статистично значима, $\mathrm{p}<0,05$.

Таблиця 14. Характеристика динамічних показників якості життя та тяжкості симптомів аритмії при жорсткому та м'якому контролі частоти серцевих скорочень (1 візит)

\begin{tabular}{|c|c|c|c|}
\hline \multirow{2}{*}{ Показник } & \multicolumn{3}{|c|}{ Середнє значення, $\overline{\boldsymbol{X}} \pm \mathrm{m}$} \\
\hline & 1, ж. к. & 1, М. к. & $\mathrm{p}$ \\
\hline SAF клас (бали) & $1,67 \pm 0,29$ & $2,05 \pm 0,19$ & 0,28 \\
\hline EHRA клас (бали) & $1,22 \pm 0,15$ & $1,67 \pm 0,13$ & 0,14 \\
\hline Міннесота (бали) & $34,33 \pm 8,34$ & $36,05 \pm 3,76$ & 0,83 \\
\hline Міннесота, фріз. фр-р (бали) & $13,33 \pm 3,24$ & $15,10 \pm 1,45$ & 0,57 \\
\hline Міннесота, ем. фр-р (бали) & $4,67 \pm 1,76$ & $5,57 \pm 1,00$ & 0,88 \\
\hline PF (фріз. фр-ння, бали) & $66,11 \pm 7,30$ & $57,38 \pm 4,55$ & 0,31 \\
\hline RP (рол. фріз. фр-ння, бали) & $47,22 \pm 12,80$ & $23,81 \pm 7,21$ & 0,87 \\
\hline ВР (інтен. болю, бали) & $61,78 \pm 9,62$ & $56,95 \pm 4,72$ & 0,78 \\
\hline GH (заг. стан здор., бали) & $43,78 \pm 4,65$ & $44,57 \pm 2,59$ & 0,87 \\
\hline VT (жит. акт., бали) & $57,22 \pm 5,66$ & $47,86 \pm 3,74$ & 0,18 \\
\hline SF (соц. фр-ння, бали) & $68,06 \pm 7,54$ & $67,26 \pm 3,90$ & 0,58 \\
\hline RE (рол. ем. фр-ння, бали) & $55,56 \pm 15,71$ & $30,15 \pm 7,94$ & 0,55 \\
\hline МН (пс. здор., бали) & $63,11 \pm 3,87$ & $60,00 \pm 3,05$ & 0,56 \\
\hline PH (фріз. к-нт. здор., бали) & $41,84 \pm 3,44$ & $38,33 \pm 1,73$ & 0,32 \\
\hline МН (псих. к-нт. здор., бали) & $42,91 \pm 3,40$ & $38,77 \pm 1,82$ & 0,25 \\
\hline
\end{tabular}

Таблиця 15. Характеристика динамічних показників якості життя та тяжкості симптомів аритмії при жорсткому та м'якому контролі частоти серцевих скорочень (2 візит)

\begin{tabular}{|l|c|c|}
\hline \multicolumn{1}{|c|}{ Показник } & \multicolumn{2}{c|}{ Середнє значення, $\bar{X} \pm \mathrm{m}$} \\
\cline { 2 - 3 } & 2, ж. к. & 2, м. к. \\
\hline SAF клас (бали) & $1,67 \pm 0,29$ & $2,05 \pm 0,19$ \\
\hline EHRA клас (бали) & $1,22 \pm 0,15$ & $1,67 \pm 0,13$ \\
\hline Міннесота (бали) & $33,78 \pm 6,81$ & $31,43 \pm 3,65$ \\
\hline Міннесота, фріз. фр-р (бали) & $12,44 \pm 2,64$ & $13,00 \pm 1,38$ \\
\hline Міннесота, ем. фр-р (бали) & $4,89 \pm 1,57$ & $4,48 \pm 1,00$ \\
\hline PF (фіз. фр-ння, бали) & $60,56 \pm 10,05$ & $56,19 \pm 5,05$ \\
\hline RP (рол. фріз. фр-ння, бали) & $44,44 \pm 16,02$ & $26,19 \pm 8,18$ \\
\hline BP (інтен. болю, бали) & $67,89 \pm 8,93$ & $62,52 \pm 4,31$ \\
\hline GH (заг. стан здор., бали) & $46,56 \pm 5,34$ & $44 \pm 3,08$ \\
\hline VT (жит. акт., бали) & $52,78 \pm 4,18$ & 0,67 \\
\hline SF (соц. фр-ння, бали) & $69,44 \pm 5,93$ & 0,58 \\
\hline RE (рол. ем. фр-ння, бали) & $51,67 \pm 3,77$ \\
\hline
\end{tabular}


Продовження табл. 13

\begin{tabular}{|c|c|c|c|}
\hline \multirow{2}{*}{ Показник } & \multicolumn{3}{|c|}{ Середнє значення, $\overline{\boldsymbol{X}} \pm \mathrm{m}$} \\
\hline & 2, ж. к. & 2, м. к. & $\mathrm{p}$ \\
\hline МН (пс. здор., бали) & $59,56 \pm 5,56$ & $60,76 \pm 2,85$ & 0,85 \\
\hline РН (фіз. к-нт. здор., бали) & $41,83 \pm 3,56$ & $39,09 \pm 1,70$ & 0,44 \\
\hline МН (псих. к-нт. здор., бали) & $42,07 \pm 2,18$ & $39,80 \pm 1,92$ & 0,49 \\
\hline
\end{tabular}

Таблиця 16. Характеристика динамічних показників якості життя та тяжкості симптомів аритмії при жорсткому та м'якому контролі частоти серцевих скорочень (3 візит)

\begin{tabular}{|c|c|c|c|}
\hline \multirow{2}{*}{ Показник } & \multicolumn{3}{|c|}{ Середнє значення, $\overline{\boldsymbol{X}} \pm \mathrm{m}$} \\
\hline & 3, ж. к. & 3, м. к. & $\mathrm{p}$ \\
\hline SAF клас (бали) & $1,67 \pm 0,19$ & $2,13 \pm 0,26$ & 0,24 \\
\hline EHRA клас (бали) & $1,27 \pm 0,12$ & $1,73 \pm 0,18$ & 0,09 \\
\hline Міннесота (бали) & $29,73 \pm 4,24$ & $33,07 \pm 4,85$ & 0,61 \\
\hline Міннесота, фріз. фр-р (бали) & $11,93 \pm 1,82$ & $13,47 \pm 1,65$ & 0,48 \\
\hline Міннесота, ем. фр-р (бали) & $4,33 \pm 1,11$ & $5,20 \pm 1,37$ & 0,48 \\
\hline PF (фріз. фр-ння, бали) & $60,67 \pm 6,88$ & $50,33 \pm 5,97$ & 0,27 \\
\hline RP (рол. фріз. фр-ння, бали) & $44,00 \pm 11,39$ & $21,67 \pm 9,40$ & 0,33 \\
\hline ВР (інтен. болю, бали) & $60,93 \pm 6,49$ & $61,33 \pm 6,54$ & 0,83 \\
\hline GH (заг. стан здор., бали) & $47,73 \pm 3,58$ & $45,80 \pm 3,85$ & 0,93 \\
\hline VT (жит. акт., бали) & $54,33 \pm 2,92$ & $50,67 \pm 4,68$ & 0,51 \\
\hline SF (соц. фр-ння, бали) & $72,50 \pm 6,00$ & $69,17 \pm 5,30$ & 0,73 \\
\hline RE (рол. ем. фр-ння, бали) & $51,11 \pm 10,72$ & $15,55 \pm 9,12$ & 0,06 \\
\hline МН (пс. здор., бали) & $63,20 \pm 2,51$ & $62,67 \pm 3,92$ & 0,91 \\
\hline PH (фріз. к-нт. здор., бали) & $40,84 \pm 2,73$ & $38,09 \pm 2,24$ & 0,44 \\
\hline МН (псих. к-нт. здор., бали) & $42,98 \pm 2,01$ & $38,44 \pm 2,27$ & 0,15 \\
\hline
\end{tabular}

ВИСНОВКИ 1. У пацієнтів із ПФФП неклапанної етіології 24-годинний ХМ ЕКГ показав себе об'єктивним показником контролю ЧСС протягом 6-місячного спостереження.

2. Застосування ББ при ПФФП має позитивний вплив на ЯЖ шляхом зниження інтенсивності симптомів $\mathrm{CH}$ за шкалою МАЯЖХСН за рахунок покращення фрізичного фрактора здоров'я.

3. Середньодобова ЧСС>91 уд./хв за даними ХМ ЕКГ $€$ предиктором негативної динаміки ТСА за шкалами EHRA i SAF.

СПИСОК ЛІТЕРАТУРИ

1. Діагностика та лікування фібриляції передсердь: рекомендації робочої групи по порушенням серцевого ритму Асоціації кардіологів України. - К., 2011. - 159 с.

2. Epidemiology of atrial fibrillation: European perspective / M. Zoni-Berisso, F. Lercari, T. Carazza, S. Domenicucci // Clin. Epidemiol. - 2014. - Vol. 6. - P. 213-220.

3. Atrial fibrillation, stroke risk, and warfarin therapy revisited: a population-based study / S. Björck, B. Palaszewski, L. Friberg, L. Bergfeldt // Stroke. - 2013. - Vol. 44. (11). - P. 3103-3108.

4. Prospective national study of the prevalence, incidence, management and outcome of a large contemporary cohort of patients with incident non-valvular atrial fibrillation / M. Haim, M. Hoshen, O. Reges [et al.] // J. Am. Heart Assoc. - 2015. - Vol. 4 (1). - E001486.

5. Chiang C. E. Distribution and risk profile of paroxysmal, persistent, and permanent atrial fibrillation in routine clinical practice: insight from the real-life global survey evaluating patients with atrial fibrillation international registry / C. E. Chiang, Naditch-L. Brûlé, J. Murin // Circ. Arrhythm. Electrophysiol. - 2012. - Vol. 5 (4). P. 632-639.
4. Жорсткий контроль демонструє більш виражений вплив на ЧСС за даними ЕКГ та ХМ ЕКГ.

5. Жодна із стратегій контролю чСС не продемонструвала своєї переваги щодо покращення ЯЖ та ТСА.

Перспективи подальших досліджень Цікавою видається можливість оцінки якості життя даної когорти пацієнтів за іншими діагнозспециорічними шкалами. Крім того, важливим аспектом є зіставлення якості життя із показниками толерантності до фрізичних навантажень, структурно-фрункціонального стану міокарда та внутрішньосерцевої гемодинаміки.

6. Clinical characteristics, management, and control of permanent vs. nonpermanent atrial fibrillation: insights from the RealiseAF survey / J. Murin, L. Naditch-Brûlé, S. Brette [et al.] // PLoS One. 2014. - Vol. 9 (1). - E86443.

7. 2016 ESC Guidelines for the management of atrial fibrillation developed in collaboration with EACTS / P. Kirchhof, S. Benussi, D. Kotecha [et al.] // Eur. Heart. J. - 2016. - Vol. 37 (38). - P. 2893-2962.

8. 2016 ESC Guidelines for the diagnosis and treatment of acute and chronic heart failure / P. Ponikowski, A. A. Voors, S. D. Anker [et al.] // Eur. Heart. J. - 2016. - Vol. 37 (27). - P. 2129-2200.

9. Lenient vs. strict rate control in patients with atrial fibrillation and heart failure: a post-hoc analysis of the RACE II study / B. A.Mulder, D. J. Van Veldhuisen, H. J. Crijns [et al.] // Eur. J. Heart Fail. - 2013 - Vol. 15 (11). - P. 311-1318.

10. Lenient versus strict rate control in patients with atrial fibrillation / I. C. Van Gelder, H. F. Groenveld, J. G. M. Harry [et al.] // N. Engl. J. Med. - 2010. - Vol. 362 (15). - P. 1363-1373.

11. Short-term ECG recordings for heart rate assessment in patients with chronic atrial fibrillation / M. Chudzik, I. Cygankiewicz, 
A. Klimczak [et al.] // Arch. Med. Sci. - 2014. - Vol. 10(4). P. 676-683.

12. Srisukwattana A. Comparison of rate assessment between resting heart rate and 24-hour Holter monitoring in patients with chronic atrial fibrillation / A. Srisukwattana, R. Krittayaphong // J. Med. Assoc. Thai. - 2012. - Vol. 95 (2). - P. 111-116.

13. Influence of heart rate on quality of life in patients with chronic atrial fibrillation / J. Jaber, C. Cirenza, J. Jaber [et al.] // Clin. Cardiol. - 2010. - Vol. 33 (4). - P 28-32.

14. Impaired quality of life in patients with intermittent atrial fibrillation / C. Nazlı, N. Kahya Eren, S. Yakar Tülüce [et al.] // Anatol. J. Cardiol. - 2016. - Vol. 16 (4). - P. 250-255.

15. The effect of rate control on quality of life in patients with permanent atrial fibrillation: data from the RACE II (Rate Control Efficacy in Permanent Atrial Fibrillation II) study / H. F. Groenveld, H. J. Crijns, M. P. Van den Berg [et al.] // J. Am. Coll. Cardiol. - 2011. - Vol. 58 (17). - P. 1795-1803.

16. Quality of life in patients with atrial fibrillation / B. Luderitz, W. Jung // Arch. Intern. Med. - 2000. - Vol. 160 (12). - P. 1749-1757.

17. Quality of life in patients with atrial fibrillation: a systematic review / G. Thrall, D. Lane, D. Carroll, G. Y. Lip // Amer. J. Med. 2006. - Vol. 119 (5). - P. 448.

18. Guidelines for the management of atrial fibrillation: the task force for the management of atrial fibrillation of the European Society of Cardiology (ESC) / A. J. Camm, P. Kirchhof, G. Y. Lip [et al.] // Eur. Heart J. - 2010. - Vol. 31 (19). - P. 2369-2429.

19. Assessment of health-related quality of life in a greek symptomatic population with atrial fibrillation: correlation with functional status and echocardiographic indices / D. Tsounis, A. Ioannidis, G. Bouras [et al.] // Hellenic J. Cardiol. - 2014. Vol. 55 (6). - P. 475-485.

20. Symptom severity is associated with cardiovascular outcome in patients with permanent atrial fibrillation in the RACE II study I R. A. Vermond, H. J. Crijns, J. G. Tijssen [et al.] // Europace. -2014. - Vol. 16 (10). - P. 1417 - 1425

21. Outcome parameters for trials in atrial fibrillation: recommendations from a consensus conference organized by the German Atrial Fibrillation Competence NETwork and the European Heart Rhythm Association / P. Kirchhof, A. Auricchio, J. Bax [et al.] // Europace. - 2007. - Vol. 9 (7). - P. 1006-1023.

22. A novel, simple scale for assessing the symptom severity of atrial fibrillation at the bedside: the CCS-SAF scale / P. Dorian, S. S. Cvitkovic, C. R. Kerr [et al.] // Can. J. Cardiol. - 2006. Vol. 22 (5). - P. 383-386.

23. Validation of a new simple scale to measure symptoms in atrial fibrillation: the Canadian Cardiovascular Society Severity in Atrial Fibrillation scale /P. Dorian, P. G. Guerra, C. R. Kerr [et al.] // Circ. Arrhythm. Electrophysiol. - 2009. - Vol. 2 (3). - P. 218-224.

24. Canadian Cardiovascular Society Atrial Fibrillation Guidelines 2010: Etiology and Initial Investigations / J. S. Healey, R. Parkash, T. Pollak [et al.] // Can. J. Cardiol. - 2011. - Vol. 27 (1). - P. 31-37.

25. Quality of life in patients with atrial fibrillation: how to assess it and how to improve it / E. Aliot, G. L. Botto, H. J. Crijns, P. Kirchhof // Europace. - 2014. - Vol. 16 (6). - P. 787-796.

26. Rector T. S. Assessment of patient outcome with the Minnesota living with heart failure questionnaire: reliability and validity during a randomized, double-blind, placebo-controlled trial of pimobendan / J. N. Rector, J. N. Cohn // Am. Heart J. - 1992. - Vol. 124 (4). P. 1017-1025.
27. Assessing health-related quality of life in patients with heart failure: a systematic, standardized comparison of available measures / O. Garin, M. Herdman, G. Vilagut [et al.] // Heart Fail. Rev. - 2014. - Vol. 19 (3). - P. 359-367.

28. Quality of life is impaired similarly in heart failure patients with preserved and reduced ejection fraction / T. Hoekstra, I. LesmanLeegte, D. J. Van Veldhuisen [et al.] // Eur. J. Heart Fail. - 2011. Vol. 13 (9) - P. 1013-1018.

29. The Minnesota living with heart failure questionnaire: comparison of different factor structures / A. Bilbao, A. Escobar, L. García-Perez [et al.] // Health and Quality of Life Outcomes. Vol. 14 (1). - P. 2-11.

30. Canadian Cardiovascular Society Atrial Fibrillation Guidelines 2010: Rate and Rhythm Management / A. M. Gillis, A. Verma, M. Talajic [et al.] // Can. J. Cardiol. - 2011. - Vol. 27 (1). - P. 47-59.

31. Makarov L. Circadian index, as an additional parameter for assessement of the heart rhythm in patients with heart failure // ISHNE Heart. Fail. World-Wide Internet Symp. - 2006. - Conference Paper.

32. Ware J. E. The MOS 36-Item Short-Form Health Survey (SF36) / J. E. Ware, C. D. Sherbourne // Med. Care. - 1992. - Vol. 30 (6). - P. 472-483.

33. Pathophysiological characterization of isolated diastolic heart failure in comparison to systolic heart failure / D. W. Kitzman, W. C. Little, P. H. Brubaker [et al.] // JAMA. - 2002. - Vol. 288 (17). - P. 2144-2150.

34. Prevalence, clinical characteristics, quality of life, and prognosis of patients with congestive heart failure and isolated left ventricular diastolic dysfunction / L. P. Badano, M. C. Albanese, P. De Biaggio [et al.] // J. Am. Soc. Echocardiogr. - 2004. - Vol. 17 (3). - P. 253-261.

35. Assessment of long-term effects of Irbesartan on heart failure with preserved ejection fraction as measured by the Minnesota living with heart failure questionnaire in the Irbesartan in heart failure with preserved systolic function (I-PRESERVE) trial // Circ. Heart. Fail. - 2012. - Vol. 5 (2). - P. 217-225.

36. Quality of life as an independent predictor for cardiac events and death in patients with heart failure / N. Kato, K. Kinugawa, S. Seki [et al.] // Circ. J. - 2011. - Vol. 75 (7). - P. 1661-1669.

37. Quality of life and survival in patients with heart failure / T. Hoekstra, T. Jaarsma, D. J. Van Veldhuisen [et al.] // Eur. J. Heart Fail. - 2013. - Vol. 15 (1) - P. 94-102.

38. Characterization of health-related quality of life in heart failure patients with preserved versus low ejection fraction in CHARM / E. F. Lewis, G. A. Lamas, E. Omeara [et al.] // Eur. J. Heart Fail. 2007. - Vol. 9 (1) - P. 83-91.

39. Lainscak M. Implementation of guidelines for management of heart failure in heart failure clinic: effects beyond pharmacological treatment/ M. Lainscak // Int. Heart J. -2004. - Vol. 97 (3). - P. 411-416.

40. Empleo de bisoprolol en la insuficiencia cardíaca. Resultados del estudio BISOCOR [Use of bisoprolol in heart failure. The BISOCOR observational study] / J. R. González-Juanatey, E. Alegría Ezquerra, V. García Saavedra [et al.] // Rev. Esp. Cardiol. - 2003. - Vol. 56 (9). - P. 873-879.

41. Safety and efficacy of carvedilol in severe heart failure / J. N. Cohn, M. B. Fowler, M. R. Bristow [et al.] // J. Card. Fail. - 1997. - Vol. 3 (3). - P. 173-179.

42. Silvet $\mathrm{H}$. Heart rate control in patients with chronic atrial fibrillation and heart failure / H. Silvet, L. A. Hawkins, A. K. Jacobson // Congest. Heart Fail. - 2012. - Vol. 19 (1). - P. 25-28. 
๑O. S. Sychov ${ }^{1}$, P. B. Romaniuk ${ }^{1}$, V. H. Hurianov ${ }^{2}$ M. Strazhesko Institute of Cardiology of NAMS of Ukraine, Kyiv ${ }^{1}$ O. Bohomolets National Medical University, Kyiv²

\section{INFLUENCE OF THE HEART RATE ON THE QUALITY OF LIFE AND SEVERITY OF ARRHYTHMIA SYMPTOMS IN PATIENTS WITH A PERMANENT ATRIAL FIBRILLATION NON-VALVULAR ETIOLOGY}

Summary. Atrial fibrillation (AF) is the most common chronic cardiac rhythm disorder and is rightly considered a 21st century epidemic. $\mathrm{AF}$ is usually associated with life quality worsening. That is why its improvement is one of the main tasks in the treatment of this group of patients.

The aim of the study - to estimate the dynamic changes in the quality of life and the severity of arrhythmia symptoms (SAS) in patients with a permanent atrial fibrillation non-valvular etiology during treatment with $\beta$-blockers (BB), determination the critical value of the heart rate as a negative dynamic predictor of the life quality and SAS during 6 month monitoring, identification the preference for one of the HR control strategies.

Material and Methods. 30 patients are consistently included in this study. The duration of observation was $238.3 \pm 17.0$ days, the design consisted in 3 visits. Titration of the BB dose lasted $67.7 \pm 10.3$ days (the interval between the first and second visits). Reception of the maximum or maximum tolerable dose of BB lasted 170.6 \pm 17.7 days (the interval between the second and final visits). ECG recording, Holter ECG, assessment of QoL and SAS were conducted during each of the visits.

Results and Discussion. During follow-up period the resting heart rate in beats/min and $\mathrm{ms}$ by ECG on the first and second visits decreased significantly. At the same time, according to Holter ECG data, such a pattern was not found. When assessing life quality and SAS values, the number of points for the Minnesota living with heart failure questionnaire (MLHFQ) was significantly reduced at the 3rd visit, and the score for the physical health factor in the same questionnaire also decreased already at the 2nd visit. The conducted correlation analysis revealed a relationship between the score on the EHRA and SAF SAS scales with the mean daily $\mathrm{HR}$ value according to $24 \mathrm{~h}$ Holter ECG. When comparing both strategies strict control showed a significant advantage for the duration of the minimum, maximum and average RR intervals in beats/min and increasing their duration in ms, and consequently, the decrease in heart rate, according to ECG data (1, 2, 3 visits); decrease (1, 2, 3 visits), the mean maximum (1, 2, 3 visits), the mean minimum (1, 2, 3 visits), the mean in the active period (1, 2, 3 visits), the mean passive period ( 1 visit) heart rate in beats/ min, circadian index (Cl) (1, 2 visits), increase mean daily (1, 2, 3 visits), the mean maximum (1, 2, 3 visits), the mean minimum $(1,2,3$ visits), the mean in the active period (2, 3 visits), the mean in the passive period ( 1 visit), heart rate in ms according to the Holter ECG data.

Conclusions. In patients with PAF non-valvular etiology during 6-month follow-up period Holter ECG was an objective indicator of heart rate control. Usage of BB for PAF has a positive effect on QoL by reducing the intensity of HF symptoms for the MLHFQ by improving the physical component of health. Fixed during Holter ECG mean daily HR> 91 beats/min is a predictor of SAS negative dynamics of the EHRA and SAF scales. Strict heart rate control shows a more pronounced effect on heart rate according to ECG and Holter ECG. None of the heart rate control strategies has demonstrated its benefits in terms of improving life quality and SAS.

Key words: permanent atrial fibrillation; heart rate control; quality of life; symptoms severity of arrhythmia.

()О. С. Сычёв ${ }^{1}$, П. Б. Романюк'1, В. Г. Гурьянов ${ }^{2}$ Государственное учреждение “Национальный научный центр “Институт кардиологии имени академика Н. Д. Стражеско" Национальной академии медицинских наук Украины", г. Киев Национальный медицинский университет имени А. А. Богомольца, г. Киев

\section{ВЛИЯНИЕ ЧАСТОТЫ СЕРДЕЧНЫХ СОКРАЩЕНИЙ НА КАЧЕСТВО ЖИЗНИ И ТЯЖЕСТЬ СИМПТОМОВ АРИТМИИ В ПАЦИЕНТОВ С ПОСТОЯННОЙ ФОРМОЙ ФИБРИЛЛЯЦИИ ПРЕДСЕРДИЙ НЕКЛАПАННОГО ГЕНЕЗА}

Резюме. Фибрилляция предсердий (ФП) - наиболее распространенное хроническое нарушение ритма сердца и по праву считается эпидемией XXI в. ФП обычно ассоциируется с ухудшением КЖ. Именно поэтому ее улучшения - одна из основных задач при лечении данной группы пациентов.

Цель исследования - оценить динамические изменения качества жизни (КЖ) и тяжести симптомов аритмии (ТСА) у пациентов с постоянной формой фибрилляции предсердий неклапанного генеза на фоне применения $\beta$-адреноблокаторов (ББ), определить критическое значение ЧСС, как предиктор негативной динамики КЖ и ТСА при 6-месячном наблюдении, выявить предпочтение одной из стратегий контроля чСС.

Материалы и методы. 30 пациентов последовательно включены в данное исследование. Длительность наблюдения составила $(238,3 \pm 17,0)$ дня, дизайн предусматривал 3 визита. Титрования дозы ББ проводилось $(67,7 \pm 10,3)$ дня (интервал между первым и вторым визитами). Прием максимальной или максимально переносимой дозы ББ длился $(170,6 \pm 17,7)$ дня (интервал между вторым и заключительным визитами). Запись ЭКГ, холтеровский мониторинг ЭКГ (ХМ ЭКГ) и анкетирование для оценки КЖ и ТСА проводились во время каждого из визитов.

Результаты исследований и их обсуждение. Через 6 месяцев в обследуемой группе пациентов значимо снизилась средняя ЧСС покоя в уд./мин и мс по результатам ЭКГ по сравнению как с первым, так и со вторым визитами. При этом по данным ХМ подобной закономерности не обнаружено. При оценке показателей КЖ и ТСА значимо уменьшилось количество баллов по The Minnesota living with heart failure questionnaire (МАКЖБСН) на 3 визите, также уменьшилось количество баллов по фризическому фрактору здоровья в этой же анкете, причем уже на 2 визите. Проведенный корреляционный анализ выявил связь количества баллов по шкалам TCA EHRA и SAF с показателем среднесуточной чСС по данным 24-х ч XM ЭКГ. При сопоставлении обеих стратегий жесткий контроль показал значимое преимущество по снижению продолжительности минимального, максимального и среднего интервалов RR в уд./мин и повышение их продолжительности в мс, а следовательно и снижение ЧСС, по данным ЭКГ (1, 2, 3 визиты); снижение средней в сутки (1, 2, 3 визиты), средней максимальной (1, 2, 3 визиты), средней минимальной (1, 2, 3 визиты), средней в активный период (1, 2, 3 визиты), средней в пассивный период (1 визит) ЧСС в уд./мин циркадного индекса (ЦИ) (1, 2 визиты) и повышение средней за сутки (1, 2, 3 визиты), средней макси- 
мальной (1, 2, 3 визиты), средней минимальной (1, 2, 3 визиты), средней в активный период (2, 3 визиты), средней в пассивный период (1 визит) ЧСС в мс данным ХМ ЭКГ.

Выводы. У пациентов с ПФФП неклапанного генеза в течение 6-месячного наблюдения 24-х часовой ХМ ЭКГ показал себя объективным показателем контроля ЧСС. Применение ББ при ПФФП имеет положительное влияние на КЖ путем снижения интенсивности симптомов СН по шкале МАЯЖХСН за счет улучшения фризического фрактора здоровья. Зафиксирована во время ХM ЭКГ среднесуточная ЧСС> 91 уд./мин является предиктором негативной динамики TCA по шкалам EHRA и SAF. Жесткий контроль демонстрирует более выраженное влияние на ЧСС по данным ЭКГ и ХМ ЭКГ. Ни одна из стратегий контроля ЧСС не продемонстрировала своего превосходства по улучшению КЖ и ТСА.

Ключевые слова: постоянная фрорма фибрилляции предсердий; контроль частоты сердечных сокращений; качество жизни; тяжесть симптомов аритмии. 